\title{
ORIGIN AND QUALITY OF THERMAL GROUNDWATERS IN THE REGION OF FARSALA (E. THESSALY/GREECE)
}

\author{
Stamatis G. ${ }^{{ }^{*}}$, Parpodis K. ${ }^{1}$, Lambrakis N. ${ }^{2}$, and Zagana E. ${ }^{2}$ \\ ${ }^{1}$ Institute of Mineralogy-Geology, Agricultural University of Athens, Iera Odos 75, 11855 Athens, \\ Greece; stamatis@aua.gr \\ ${ }^{2}$ Laboratory of Hydrogeology, Department of Geology, University of Patras, 26110 Rio, Patras, \\ Greece; nlambrakis@upatras.gr
}

\begin{abstract}
Farsala Basin presents a remarkable geothermal interest. Areas exhibiting geothermal potential are directly related to faulted zones, represented mainly by cross-faulted systems of E-W, NW-SE and NNE-SSW direction. Thermal waters occur in the areas of Ampelia and Krini in boreholes of $420 \mathrm{~m}$ depth. Their temperature ranges between $20,5^{\circ}$ and $39,1^{\circ}$ C. Thermal waters originate from meteoric waters, which have been infiltrated and heated in great depths, moved towards the surface through faults and hosted in the aquifers of coarse - grained formations find in the area. Their chemical composition is controlled by their contact with the volcanic parts (pillow lavas) of the ophiolithic series. They show alkaline character and low salts concentration. Waters of Ampelia region, which belong to $\mathrm{Na}-\mathrm{HCO}_{3}$ type, exhibit temperatures from $27,9^{\circ}$ to $39,1^{\circ} \mathrm{C}$ and low salt concentrations (405$607 \mathrm{mg} / \mathrm{l} \mathrm{TDS})$. On the contrary, waters of Krini area present lower temperatures $\left(20,5^{\circ}-26,2^{\circ} \mathrm{C}\right)$ and higher salt concentrations $(734-1850 \mathrm{mg} / \mathrm{l}$ $\mathrm{TDS}$ ). These waters belong to $\mathrm{Na}-\mathrm{Mg}-\mathrm{Ca}-\mathrm{HCO}_{3}$ and $\mathrm{Na}-\mathrm{SO}_{4}-\mathrm{Cl}-\mathrm{HCO}_{3}$ types. According to chemical geothermometers the study area can be classified to low enthalpy geothermal field, since the estimated thermal liquids temperature in great depths varies from $50^{\circ}$ to $70^{\circ} \mathrm{C}$.

Key words: Thermal waters, Hydrogeochemistry, Geothermometry, Farsala basin, Greece.
\end{abstract}

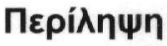

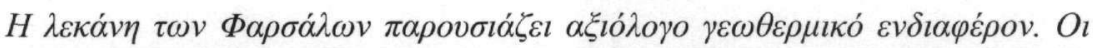

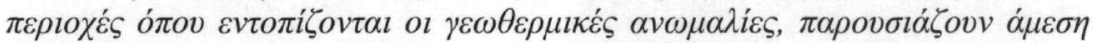

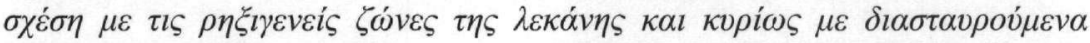

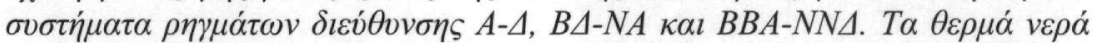

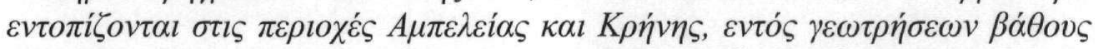

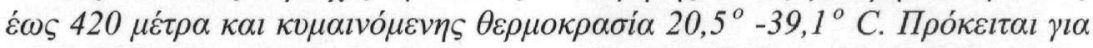

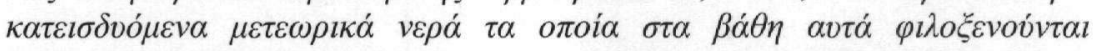

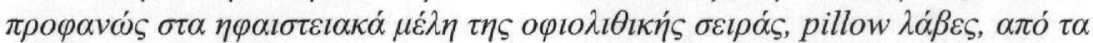

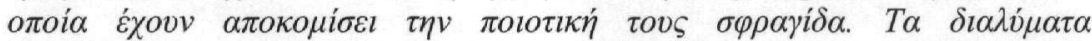

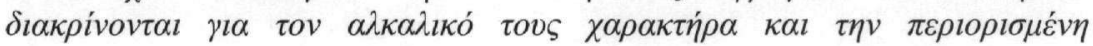




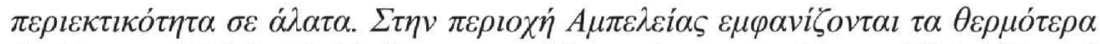

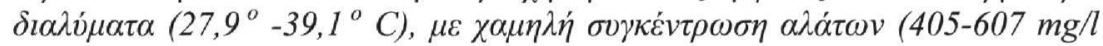

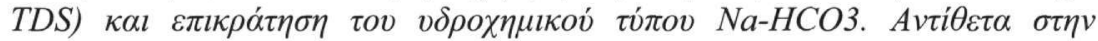

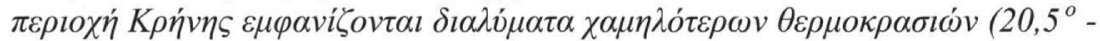

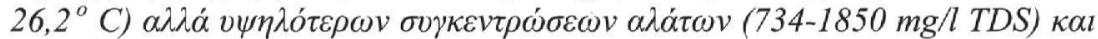

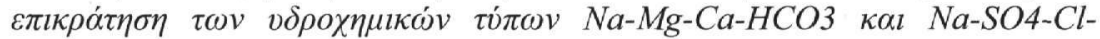

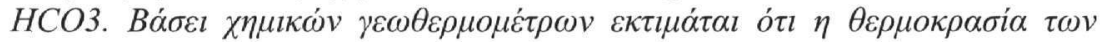

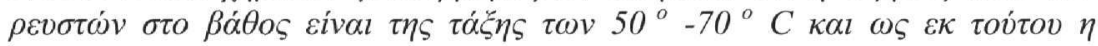
$\pi \varepsilon \rho \iota \chi^{\prime} \dot{~ \varepsilon ́ \rho \varepsilon v v \alpha \varsigma ~ \kappa \alpha \tau \alpha \tau \alpha ́ \sigma \sigma \varepsilon \tau \alpha l ~ \sigma \tau \alpha ~ \gamma \varepsilon \omega \theta \varepsilon \rho \mu ı к \alpha ́ ~ \pi \varepsilon \delta i ́ \alpha ~ \chi \alpha \mu \eta \lambda \eta ́ \varsigma ~ \varepsilon v \theta \alpha \lambda \pi i ́ \alpha \varsigma . ~}$

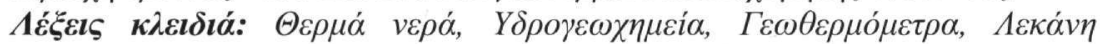
$\Phi \alpha \rho \sigma \alpha \lambda \omega v, E \lambda \lambda \dot{\alpha} \delta \alpha$.

\section{Introduction}

The basic aim of this work is the study of the chemical characteristics of groundwater hosted in different hydro-lithological units of Farsala Basin. The existence of thermal groundwaters mainly in deep boreholes of particular areas of the basin was confirmed during the fieldwork. According to the record of water-occurrences, the water temperature measurements and the results of chemical analyses, two characteristic areas of different thermal groundwater quality were detected. The geology of the study area presents a variety of lithological types and an intense tectonic activity, which is reflected on several faulted zones. The circulation of meteoric waters in deep stratigraphic horizons and high temperature environments, in which ground thermal liquids are finally hosted, is obviously accomplished through the abovementioned-faulted zones. There is a lack in thermal liquids surface activities in the study area. This is also observed in Spercheios Basin (located southern from Farsala Basin), where a great number of thermal springs and regions of intense geothermal activity exist (Sfetsos 1988, Papadeas 1996, Gartzos et al. 1996). Since the local economy is based on agriculture and farming, geothermal waters, if exploited properly, could support several activities such as glass houses, farming, siccative activities and spa establishments. The paper presents the geothermal status of the area, describes the chemical character of thermal waters, interprets their origin, explains the processes taking place within the geothermal system and evaluates the temperature of the geothermal reservoir.

\section{Study Area}

\subsection{Geological Setting}

The study area takes part of the East Greece Geotectonic Unit and includes alpine and post- alpine formations (Fig. 1). The youngest post-alpine formations of the study area are consisted of a) recent Holocene deposits, alluvial sediments and talus cones, which cover the lowland of the basin, b) Neogene formations mainly of fluvio-lacustrine and lacustrine-brakish-marine origin that occupy a large area in the north part of the basin and c) Plio-Pleistocene terrestrial deposits, which are developed at the lower topographic parts of the south and east margins of the basin. The alpine formations form the sub-basement of the sediments in the major part of the basin. They consist of:

a) Flysch of Upper Cretaceous age: mainly fine-, mid- grained and in some places coarsegrained clayey sandstones, conglomerates and intercalations of marly and sandy limestones. It is located mainly at the east and north margins of the basin overlaying the Cretaceous carbonates (Bornovas et al 1969, Katsikatsos et al 1983).

b) Limestones: Upper Cretaceous transgressive limestones mainly mid - plated and in some places thick- and thin-plated, microcrystalline, karstified with marly intercalations, located mainly at the east and west margins of the basin.

c) Ophiolites: They consist of serpentinites, dunites and peridotites, underlying by the upper Cretaceous limestones and overthrusting the metamorphic formations of the Triassic- 
Jurassic platform. They form the Pre-Upper Cretaceous tectonic nappe. The ophiolites consist mainly of volcanic rocks (pillow lavas) in Farsala area and in some cases of ultrabassic intense serpentinised formations. In the broad area of Orthris, pillow lavas present high alkaline concentrations $\left(\mathrm{Na}_{2} \mathrm{O}: 3,4-5,4 \% \kappa \alpha \mathrm{K}_{2} \mathrm{O}: 0,1-1,7 \%\right)$ (Ferriére 1982). Intense fractured and seprentinised ultrabasic bodies with important chromite concentrations appear in the east part of the basin (Eretria area). The Ophiolite masses overlay the Jurassic Schists (Katsikatsos et al 1983, Migiros 1990).

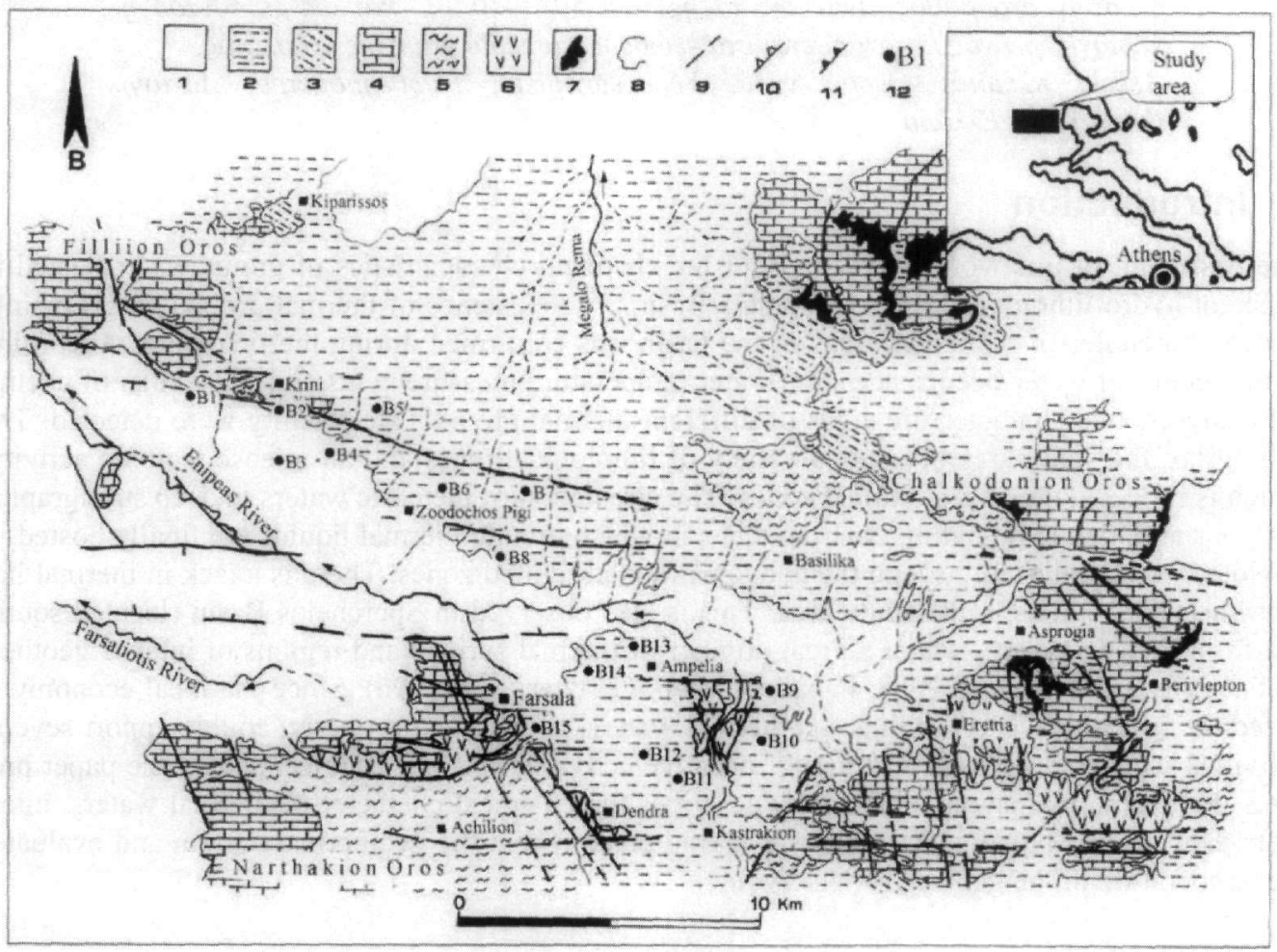

Figure 1 - A simplified geological map of the study area (Bornovas et al. 1969, Katsikatsos et al. 1983, Mariolakos et al. 2001b), (1: Holocene deposits, 2: Neogene formations, carbonates, marls, conglomerates, sands, etc, 3: Flysch of Upper Cretaceous, 4: Limestones of Upper Cretaceous, 5: Schists and phyllites of Upper Cretaceous and Jurassic, 6: Ophiolites of PreUpper Cretaceous tectonic nappe, 7: Paleocene Olistholiths and Olisthostromes "Krini formations", 8: Geological boundary, 9: Fault, 10: Overthrust pre-uppercretaceous, 11: Overthrust post- uppercretaceous, 12 : Sampling boreholes for chemical analyses

d) Schist - formations: The southern part of Farsala Basin is covered by schist and hornfels formations, which consist of clayey schists and cherts with conglomerates and limestones intercalations. The schists in the east part of the study area are chloritic-sericitic- epidotic, intensively alternating with marbles, sipolines and crystalline intercalations. Their visible thickness is approximately $400 \mathrm{~m}$ and they are probably of Jurassic Age (Bornovas et al. 1969, Katsikatsos et al. 1983).

e) Olistholiths and Olisthostromes: They consist of serpentinites, diabasic-dioritic-grabbro rocks, carbonate and dolomite parts, which have been deposited unconformably on the above-mentioned formations. They form a particular tectonic unit known as "Krini formations" (Katsikatsos et al. 1983). These formations are restricted northern of Chalkodonion Mounatin and east of Eretria. 
The tectonic structure of the study area is characterized by E-W trending faults, which mainly control the basin development and by NNW-SSE trending faults (Fig. 1).

\subsection{Hydrogeology}

Three different aquifer types occur in the study area, which are related with the various lithological units. An unconfined aquifer of important potentiality is developed in the unconsolidated deposits of the basin and suffers from overexploitation due to the supply of the irrigation needs of the area. The thickness of the unconsolidated deposits ranges from a few meters eastern of the basin to a few ten meters westwards, to more than $200 \mathrm{~m}$ in the central and northern parts of the basin, particularly within the tectonic grabens (Mariolakos et al. 2001a, 2001b). Groundwater flows from the east to the west parts of the basin. The absolute groundwater level reaches $140 \mathrm{~m}$ asl in the east part, whereas in the west part is $110 \mathrm{~m}$ asl. Generally, due to the overexploitation of the unconfined aquifer, a groundwater level decrease is observed, which is calculated at 3-6 m/a. (Kallergis et al.1970, Mariolakos et al. 2001a, 2001b). A karst aquifer of important potentiality is developed within the karstified carbonate formations. The major karst springs of the region, such as Vrisia and Chtouri springs, located west of the Farsala city, are fed from the carbonate formations of Narthakio and Filio Mt in the west part of the basin. The discharge of these springs shows an obvious decrease and falls dry in hot periods. This could be also attributed to the overexploitation of the karst aquifer (Mariolakos et al. 2001a, 2001b). The carbonate masses developed in the east part of the basin probably feed laterally the unconsolidated formations of the basin. An aquifer of low potentiality is developed in the fractured crystalline formations. The discharge of the deep boreholes in the ultrabasic rocks does not exceed $30 \mathrm{~m}^{3} / \mathrm{h}$. Within the Neogene sandy and carbonate horizons an aquifer of low potentiality occurs. The discharge of the boreholes, when the formation thickness and structure are favourable, reaches the $20-30 \mathrm{~m}^{3} / \mathrm{h}$.

\section{Methodology}

All boreholes in the study area were recorded during July and August 2005. In a network of 95 equally distributed boreholes in the study area, temperature measurements were taken during their pumping. Samples for chemical analyses were collected from 15 boreholes, according to their temperature and origin region. Physicochemical parameters were measured in situ with the use of portable devices: $\mathrm{T}^{0} \mathrm{C}$ and $\mathrm{EC}$ (WTW/LF-330), $\mathrm{pH}$ (WTW/pH-330i) and dissolved oxygen DO (WTW/OXI-96). Titration methods were used for the determination of $\mathrm{CO}_{2}$, and $\mathrm{H}_{2} \mathrm{~S}$ concentrations. Samples were collected in plastic polyethylene bottles and analysed for $\mathrm{Ca}^{2+}, \mathrm{Mg}^{2+}$, $\mathrm{Na}^{+}, \mathrm{K}^{+}, \mathrm{HCO}_{3}{ }^{-}, \mathrm{Cl}^{-}, \mathrm{SO}_{4}{ }^{2-}, \mathrm{NO}_{3}{ }^{-}, \mathrm{NH}_{4}{ }^{+}, \mathrm{PO}_{4}{ }^{3-}, \mathrm{I}^{-}, \mathrm{F}^{-}, \mathrm{Br}^{-} \mathrm{B}-\mathrm{SiO}_{2}$, total and carbon hardness. For the determination of $\mathrm{Fe}, \mathrm{Mn}, \mathrm{Cu}$, and $\mathrm{Zn}$ samples were collected and preserved in the field. They filtered, acidified to $\mathrm{pH}<2$ with upltrapure $\mathrm{HNO}_{3}$ and then collected in $100 \mathrm{ml}$ plastic polyethylene bottles. All chemical analyses were conducted in the laboratory of Mineralogy-Geology Institute at the Agricultural University of Athens. Cations were determined using atomic absorption (GBC908AA), while anions apart of $\mathrm{Cl}^{-}$, were measured with spectrophotometer (HACK-DR/3000). For the assessment of total and carbon hardness as well as $\mathrm{Cl}^{-}$, titration methods were applied: Titriplex-Lösung A, $\mathrm{HCl} 0,1 \mathrm{~N}$ and $\mathrm{AgNO}_{3} 0,1 \mathrm{~N}$ respectively (Höll 1979).

\section{Results}

\subsection{Geothermal study}

The study area takes part of the broader area of East Sterea, where a heat flow increase is observed, related to the late orogenetic volcanism and the creation of the South Aegean Volcanic Arc (Fytikas et al. 1979). The late orogenetic volcanic centers of Lichades (North Evoikos Gulf) and Mikrothives (NE Orthis Mt) evidence the northwest end of the Volcanic Arc into the study area. Figure 2 presents the groundwater temperature distribution according to the measurements from a 95-borehole network. The temperature was measured during the pumping of groundwater samples. 


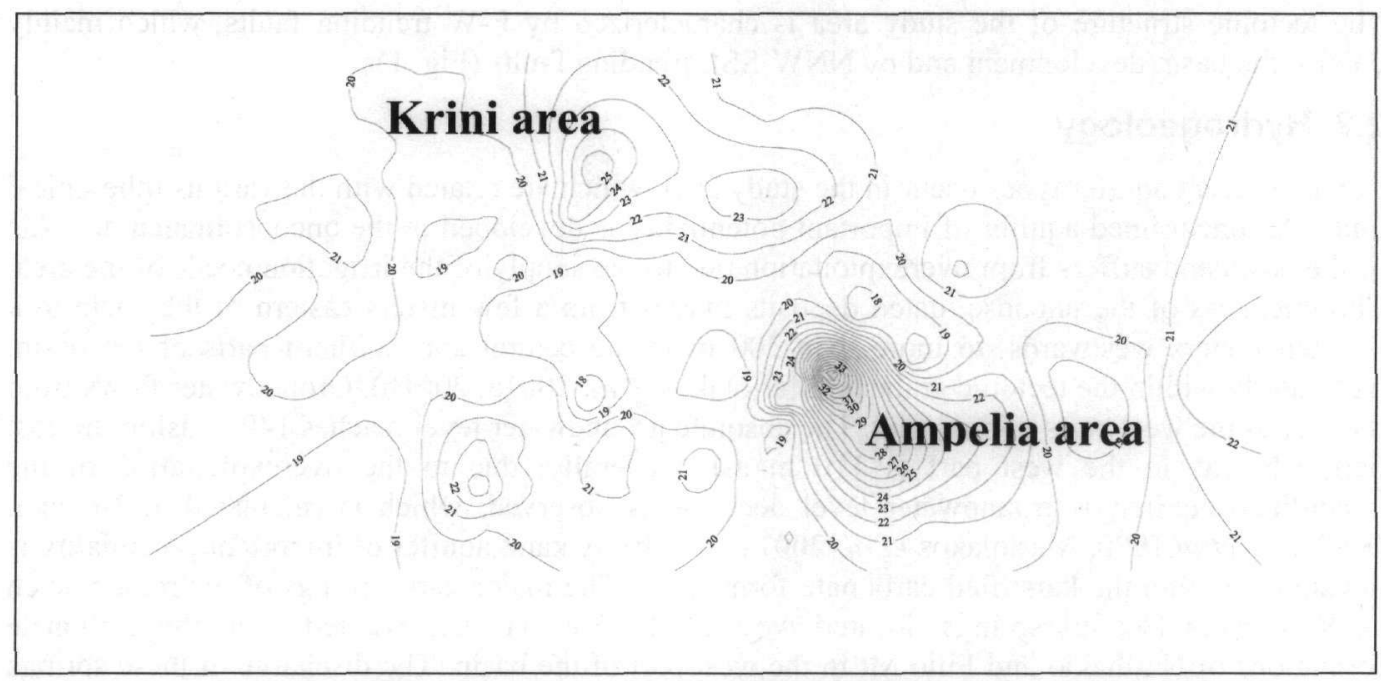

Figure 2 - Groundwater temperature distribution in Farsala Basin

The lowest temperatures ranging from $16,5^{\circ} \mathrm{C}$ to $19,5^{\circ} \mathrm{C}$ are observed in boreholes in central and west parts of the alluvial basin. These boreholes are located in depths from 45 to $312 \mathrm{~m}$ and many of them reach negative levels up to $-170 \mathrm{~m}$ (below sea level). Thermal waters in boreholes located in depths between 100 and $150 \mathrm{~m}$ reveal temperatures from $16,5^{\circ} \mathrm{C}$ to $18,5^{\circ} \mathrm{C}$, while thermal waters of greater depths exhibit temperatures from $18,5^{\circ} \mathrm{C}$ to $19,5^{\circ} \mathrm{C}$. This temperature increase indicates the presence of geothermal activity in deeper aquifers. The groundwater temperature of the region between Krini and Zoodocho Pigi communities (Fig. 1) in the northwest part of the study area reaches $26,2^{\circ} \mathrm{C}$ (borehole B5). The borehole B5 is located in a $350 \mathrm{~m}$ depth and reaches negative levels up to $-130 \mathrm{~m}$ (bsl). Temperature increase is also observed along the zone of the north slopes of the basin, which coincides with the fractured zone of the area. The groundwater temperature in the boreholes of this area ranges from $21,2^{\circ} \mathrm{C}$ to $24,2^{\circ} \mathrm{C}$. Thermal groundwaters of $39,1^{\circ} \mathrm{C}$ temperature are recorded in the region between Dendra and Ampelia communities (Fig. 1) in the central-south part of the study area. The borehole B13, where the highest temperature value is observed, is located in a depth of $400 \mathrm{~m}$ and reaches $-200 \mathrm{~m}$ bsl. According to Thurner (1967) and based on the temperature measurements, thermal waters of the study area are classified as slightly thermal $\left(20^{\circ}-25^{\circ} \mathrm{C}\right)$, thermal $\left(25^{\circ}-32^{\circ} \mathrm{C}\right)$ and very thermal $\left(>32^{\circ} \mathrm{C}\right)$. Thermal waters from $\mathrm{B} 13$ belong to the third type, whereas B3, B5, B11, B12 and B15 boreholes belong to the second group. The rest of the boreholes belong to the first type.

\subsection{Chemistry of thermal waters}

Chemical data from all samples of the study area are provided in Table 1. Thermal groundwaters of Krini and Ampelia areas display differences not only in temperature but also in their chemical character.

In Krini region, the groundwater temperature ranges from $20,5^{\circ} \mathrm{C}$ to $26,2^{\circ} \mathrm{C}$. Thermal waters exhibiting the highest temperature of $26,2^{\circ} \mathrm{C}$ (borehole B5) in this region, present also the highest conductivity $(2170 \mu \mathrm{S} / \mathrm{cm})$ and the highest TDS value $(1850 \mathrm{mg} / \mathrm{l})$. Electrical conductivity and TDS values of the rest thermal groundwaters vary from 795 to $1146 \mu \mathrm{S} / \mathrm{cm}$ and from 734 to 979 $\mathrm{mg} / \mathrm{l}$ respectively. They present alkaline character $(7,3-8,1 \mathrm{pH})$ and low $\mathrm{O}_{2}$ concentration $(1,6-5,7$ $\mathrm{mg} / \mathrm{l})$. The $\mathrm{CO}_{2}$ concentration ranges from 18 and $32 \mathrm{mg} / \mathrm{l}$, whereas the $\mathrm{H}_{2} \mathrm{~S}$ concentration varies between 0,3 and $1,8 \mathrm{mg} / 1$. The Borehole $\mathrm{B} 13$ with the highest temperature $\left(39,1^{\circ} \mathrm{C}\right)$ of the study area is located in Ampelia region. In the other boreholes of Ampelia region the groundwater temperature ranges between $22,4^{\circ} \mathrm{C}$ and $28,8^{\circ} \mathrm{C}$. Thermal groundwaters of Ampelia area are characterized by low TDS values (405-942 mg/1 TDS), low electrical conductivity values (366- 
$1091 \mu \mathrm{S} / \mathrm{cm})$ and high $\mathrm{pH}$ values $(7,8$ and 8,7$)$. They present low $\mathrm{O}_{2}$ concentration $(0,2-5,4 \mathrm{mg} / \mathrm{l})$. The $\mathrm{CO}_{2}$ concentration ranges from $14 \mathrm{mg} / \mathrm{l}$ to $30 \mathrm{mg} / \mathrm{l}$, whereas the $\mathrm{H}_{2} \mathrm{~S}$ concentration varies between $1,2 \mathrm{mg} / 1$ and $5,6 \mathrm{mg} / 1$. The thermal waters (borehole B16) with the highest temperature of $39,1^{\circ} \mathrm{C}$ present the lowest TDS value $(405 \mathrm{mg} / \mathrm{l})$. In figure 3 is shown thermal waters of Krini and Ampelia region in a Piper diagram. Thermal waters of Krini region present the following hydrochemical types: a) $\mathrm{Mg}-\mathrm{Na}-\mathrm{HCO}_{3}$ (B3, B6, B7, B8), b) $\mathrm{Na}-\mathrm{Mg}-\mathrm{Ca}-\mathrm{HCO}_{3}$ (B2, B4) and c) $\mathrm{Na}-\mathrm{SO}_{4}-\mathrm{Cl}-\mathrm{HCO}_{3}$ (B5). The most thermal waters of Ampelia region present an indeterminate type of $\mathrm{Mg}-\mathrm{Ca}-\mathrm{Na}-\mathrm{Cl}-\mathrm{HCO}_{3}$ (B9, B10, B12, B14, B15). Thermal waters from B11 and B13 exhibit the types $\mathrm{Na}-\mathrm{Cl}-\mathrm{HCO}_{3}$ and $\mathrm{Na}-\mathrm{HCO}_{3}$.

Table 1 - Results of chemical analyses

\begin{tabular}{|c|c|c|c|c|c|c|c|c|c|c|c|c|c|c|c|}
\hline \multirow{4}{*}{\begin{tabular}{|l} 
\\
Boreholes \\
Sampling \\
Abs. Allt. (m)
\end{tabular}} & \multicolumn{8}{|c|}{$\begin{array}{c}\text { Thermal waters of Krini area } \\
T: 20,5-26,2^{\circ} \mathrm{C}\end{array}$} & \multicolumn{7}{|c|}{$\begin{array}{c}\text { Thermal waters of Ampelia area } \\
\text { T: } 22,4-39,1^{\circ} \mathrm{C}\end{array}$} \\
\hline & B1 & B2 & B3 & B4 & B5 & B6 & B7 & $\mathrm{B} 8$ & B9 & $\mathrm{B} 10$ & B11 & B12 & B13 & B14 & $\mathrm{B} 15$ \\
\hline & \multicolumn{4}{|c|}{2.7 .05} & \multicolumn{4}{|c|}{13.7 .05} & \multicolumn{7}{|c|}{14.7 .05} \\
\hline & 133 & 152 & 131 & 162 & 223 & 182 & 215 & 181 & 212 & 262 & 273 & 264 & 203 & 194 & 212 \\
\hline Depth ( m) & 250 & 100 & 220 & 180 & 350 & 80 & 420 & 100 & 160 & 100 & 300 & 400 & 400 & 200 & 250 \\
\hline$Q\left(\mathrm{~m}^{3} / \mathrm{h}\right)$ & 30 & 40 & 30 & 50 & 70 & 80 & 55 & 40 & 45 & 50 & 60 & 70 & 110 & 65 & 55 \\
\hline $\mathrm{T}^{0} \mathrm{C}$ & 20.5 & 21.2 & 25.2 & 23.2 & 26.2 & 23.2 & 24.4 & 21.2 & 22.4 & 23.6 & 28.8 & 27.9 & 39.1 & 24.3 & 26.2 \\
\hline EC $\mu \mathrm{S} / \mathrm{cm}$ & 795 & 1146 & 795 & 868 & 2170 & 1050 & 960 & 970 & 587 & 865 & 675 & 655 & 366 & 1091 & 434 \\
\hline $\mathrm{pH}$ & 7.3 & 7.4 & 7.6 & 7.5 & 7.9 & 7.6 & 8.1 & 7.7 & 7.8 & 7.1 & 7.9 & 7.8 & 8.7 & 7.2 & 7.8 \\
\hline $\mathrm{O}_{2} \quad \mathrm{mg} / \mathrm{l}$ & 5.7 & 5.2 & 4.1 & 4.5 &.. & 1.7 &.. & 1.6 & 5.4 & 4.8 & 0.7 & 0.4 & 0.2 & 1.4 & 0.6 \\
\hline $\mathrm{CO}_{2} \mathrm{mg} / \mathrm{l}$ & 18 & 22 & 28 & 20 & 32 & 24 & 28 & 20 & 24 & 22 & 14 & 30 & 20 & 28 & 32 \\
\hline $\mathrm{H}_{2} \mathrm{~S} \mathrm{mg} / \mathrm{l}$ & 0.6 & 1.6 & 1.4 & 0.8 & 1.8 & 1.2 & 1.2 & 0.6 & 1.4 & 1.2 & 4.2 & 2.1 & 5.6 & 2.4 & 1.8 \\
\hline Tot. Hardn. ${ }^{\circ} \mathrm{dH}$ & 21.8 & 28.1 & 13.6 & 17.2 & 24.2 & 23.7 & 22.5 & 20.0 & 11.2 & 22.0 & 5.0 & 9.5 & 1.8 & 27.4 & 11.0 \\
\hline Temp. $"{ }^{0} \mathrm{~d} H$ & 17.6 & 17.1 & 17.4 & 21.8 & 17.9 & 24.4 & 23.2 & 21.3 & 12.9 & 16.8 & 11.2 & 14.3 & 8.4 & 19.6 & 10.6 \\
\hline Perm. $\quad "{ }^{0} \mathrm{dH}$ & 4.2 & 11.0 & 0.0 & 0.0 & 6.3 & 0.0 & 0.0 & 0.0 & 0.0 & 5.2 & 0.0 & 0.0 & 0.0 & 7.8 & 0.4 \\
\hline $\mathrm{mg} / 1$ & 77.6 & 92.0 & 36.0 & 46.4 & 84.0 & 44.8 & 48.0 & 32.0 & 33.6 & 108.0 & 23.2 & 36.8 & 8.1 & 92.0 & 30.4 \\
\hline $\mathrm{Mg}^{2+}$ & 47.5 & 66.1 & 37.2 & 46.5 & 53.9 & 75.8 & 68.7 & 67.5 & 28.4 & 30.0 & 12.2 & 19.1 & 3.1 & 63.0 & 29.5 \\
\hline $\mathrm{mg} / 1$ & 38.8 & 59.8 & 100.2 & 96.9 & 413.0 & 99.6 & 100.0 & 107.2 & 60.4 & 60.4 & 130.0 & 103.5 & 89.6 & 69.0 & 25.3 \\
\hline $\mathrm{mg} / \mathrm{l}$ & 1.1 & 10.0 & 3.0 & 1.4 & 4.0 & 4.0 & 3.6 & 3.6 & 1.4 & 2.8 & 2.5 & 2.0 & 1.4 & 1.2 & 0.6 \\
\hline $\mathrm{NH}_{4}^{+}$ & 0.01 & 0.65 & 0.98 & 0.15 &.. & 7.43 & 1.51 & 0.21 & 0.00 & 0.04 & 0.19 & 0.17 & 0.26 & 0.52 & 0.00 \\
\hline $\mathrm{HCO}_{3}^{-}$ & 384.3 & 372.1 & 378.2 & 475.8 & 390.4 & 530.7 & 506.3 & 463.6 & 280.6 & 366.0 & 244.1 & 311.1 & 183.1 & 427.1 & 231.8 \\
\hline $\mathrm{mg} / \mathrm{l}$ & 53.2 & 92.2 & 67.4 & 53.2 & 319.1 & 85.1 & 53.2 & 81.6 & 53.2 & 85.1 & 95.7 & 63.8 & 39.1 & 99.3 & 28.4 \\
\hline $\mathrm{SO}_{4}{ }^{2-}$ & 44.0 & 103.2 & 80.0 & 38.1 & 510.0 & 98.2 & 100.4 & 80.8 & 10.4 & 41.6 & 47.2 & 32.2 & 20.1 & 79.1 & 51.3 \\
\hline $\mathrm{NO}_{3}{ }^{-}$ & 53.2 & 83.6 & 13.6 & 24.2 & 28.6 & 13.6 & 29.9 & 24.6 & 32.5 & 43.1 & 11.4 & 12.3 & 7.5 & 80.1 & 7.9 \\
\hline $\mathrm{PO}_{4}{ }^{3-}$ & 0.38 & 0.38 & 6.21 & 0.34 & 0.11 & 0.18 & 0.19 & 0.28 & 0.24 & 0.24 & 0.33 & 1.25 & 0.32 & 0.31 & 0.21 \\
\hline $\mathrm{mg} / \mathrm{l}$ & 0.02 & 0.11 & 0.04 & 0.04 & 0.04 & 0.01 & 0.02 & 0.06 & 0.01 & 0.00 & 0.05 & 0.18 & 0.13 & 0.15 & 0.44 \\
\hline $\mathrm{mg} / 1$ & 0.00 & 0.00 & 0.00 & 0.00 & 0.01 & 0.01 & 1.22 & 0.00 & 0.00 & 0.00 & 0.27 & 0.36 & 0.69 & 0.76 & 0.00 \\
\hline $\mathrm{mg} / \mathrm{l}$ & 0.04 & 0.08 & 0.02 & 0.03 & 0.06 & 0.01 & 0.02 & 0.04 & 0.01 & 0.00 & 0.10 & 0.10 & 0.02 & 0.01 & 0.28 \\
\hline $\mathrm{mg} / \mathrm{l}$ & 33.4 & 33.2 & 20.8 & 24.4 & 46 & 19.2 & 21.6 & 21.8 & 27.6 & 34 & 25.7 & 23.5 & 51.4 & 29.2 & 33.2 \\
\hline ppm & $<0,001$ & $<0,001$ & $<0,001$ & 0.151 & 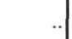 & $<0,001$ & $<0,001$ & $<0,001$ & $<0,001$ & $<0,001$ & 0.094 & 0.202 & $<0,001$ & 0.228 & $<0,001$ \\
\hline $\mathrm{Mn}^{2+}$ & $<0,001$ & $<0,001$ & $<0,001$ & $<0,001$ & .. & $<0,001$ & $<0,001$ & $<0,001$ & $<0,001$ & $<0,001$ & $<0,001$ & $<0,001$ & $<0,001$ & $<0,001$ & $<0,001$ \\
\hline $\mathrm{ppm}$ & $<0,001$ & 0.460 & $<0,001$ & $<0,001$ & .. & $<0,001$ & 0.003 & $<0,001$ & $<0,001$ & 0.125 & $<0,001$ & $<0,001$ & $<0,001$ & $<0,001$ & $<0,001$ \\
\hline $\mathrm{Cu}^{2+}$ & 0.035 & 0.045 & 0.044 & 0.049 & $\because$ & 0.037 & 0.060 & 0.054 & 0.061 & 0.058 & 0.052 & 0.050 & 0.067 & 0.069 & 0.047 \\
\hline TDS & 734 & 914 & 745 & 807 & 1850 & 979 & 935 & 884 & 529 & 772 & 593 & 607 & 405 & 942 & 440 \\
\hline
\end{tabular}

The concentrations of the surface pollutants present a significant decrease in relation to the groundwater concentrations of the above-mentioned boreholes. $\mathrm{NO}_{3}{ }^{-}$and $\mathrm{NH}_{4}{ }^{+}$concentrations range from $7,5 \mathrm{mg} / 1$ to $12,3 \mathrm{mg} / 1$ and from $0,19 \mathrm{mg} / 1$ to $0,26 \mathrm{mg} / 1$ respectively. In borehole $\mathrm{B} 12$, thermal waters present the highest $\mathrm{PO}_{4}{ }^{3-}$ concentration $(1,25 \mathrm{mg} / \mathrm{l})$. This group of alkaline thermal waters exhibit also high concentrations of $\mathrm{I}^{-}(0,05-0,18 \mathrm{mg} / \mathrm{l}), \mathrm{F}^{-}(0,27-0,69 \mathrm{mg} / \mathrm{l})$ and $\mathrm{Br}^{-}(0,02-$ $0,10 \mathrm{mg} / \mathrm{l})$. These waters originated from the mixed group of thermal waters infiltrating at great depths hold their $\mathrm{HCO}_{3}{ }^{-}$concentration and deposited a great amount of earth-alkaline $\left(\mathrm{Ca}^{2+}\right.$ and $\mathrm{Mg}^{2+}$ ). After that, they were enriched mainly with $\mathrm{Na}^{+}$ions and secondarily with $\mathrm{Cl}^{-}$and $\mathrm{SO}_{4}{ }^{2-}$ ions. The lithology of the aquifer, the tectonic structure of the greater area and the temperature status contributed to the creation of these waters. The direct participation of seawater in the 


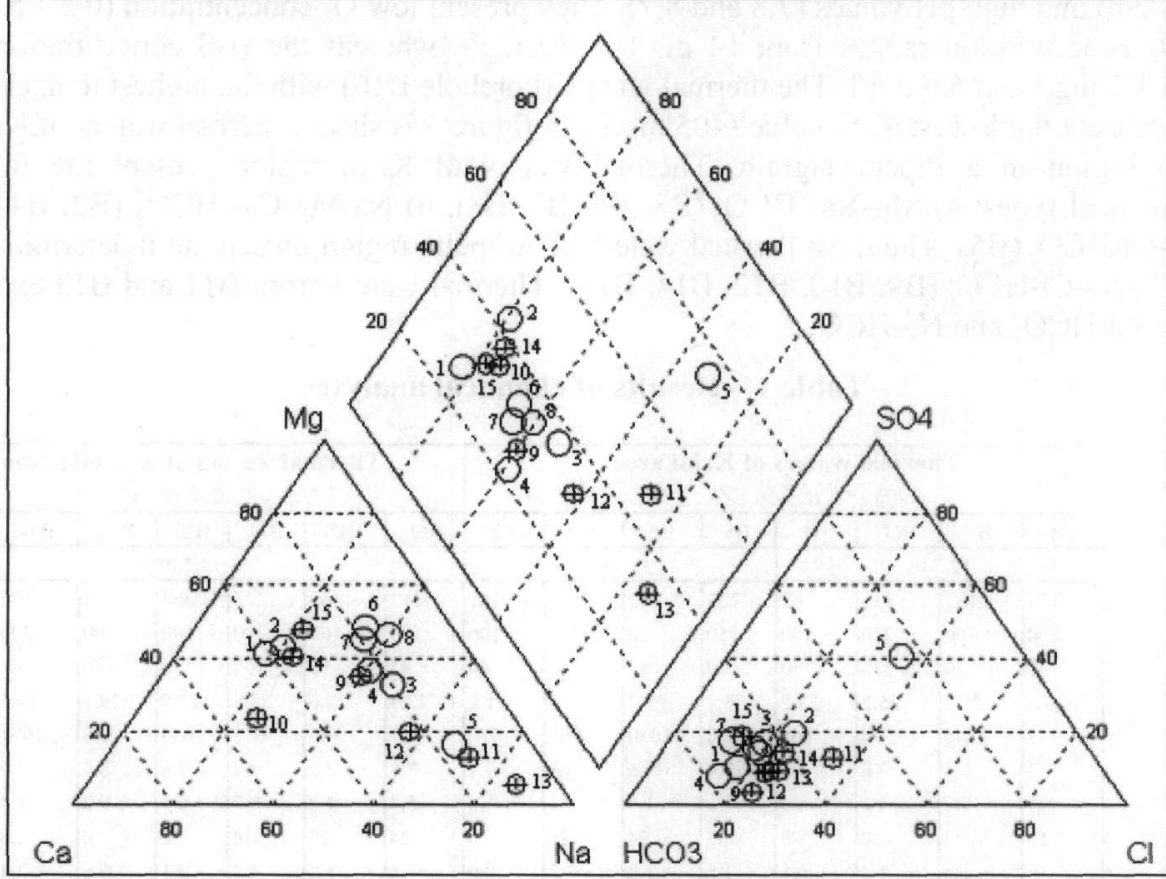

Figure 3 - Classification of thermal waters in Piper Diagram $\rho$ : thermal waters in Krini area, $\oplus$ : thermal waters in Ampelia area)

establishment of the quality character of the solutions is under question despite the observed increase of $\mathrm{Na}^{+} \mathrm{Cl}^{-}$and $\mathrm{SO}_{4}{ }^{2-}$ ions especially in Krini area. The high concentrations of these ions are mainly attributed to the dilution of evaporates of the Neogene formations developed in the area and less to the seawater intrusion. The Neogene deposits of the area are of lacustrine and marine origin and probably contain evaporates (Bornovas et al. 1969). In Ampelia area, where pillow lavas are dominated, the presence of minerals enriched with $\mathrm{Cl}^{-}$ions is also not excluded. These pillow lavas were created in sea environment and the contribution of halogens to the crystal structure of clay-silica minerals is considered to be viable. The presence of $\mathrm{SO}^{2-}$ ions is related to oxidation of iron-pyrite, which is contained in pillow lavas and dilution of secondary hydrothermal gypsum, which coexist in limited concentrations within volcanic rocks. The Piper diagram in fig. 3 confirms that besides sample from $\mathrm{B} 5$ borehole, $\mathrm{SO}_{4}{ }^{2-}$ concentrations are gradually decreased compared to $\mathrm{Cl}^{-}$and $\mathrm{HCO}_{3}^{-}$ones. This is a characteristic phenomenon of thermal and seawater mixture. From the $\mathrm{Cl} / \mathrm{Na}$ correlation diagram (fig. 4), it is also shown that all types of waters tend to mix with seawater. Nevertheless, this is not confirmed from the $\mathrm{Cl} / \mathrm{HCO}_{3}{ }^{-}$relation diagram.

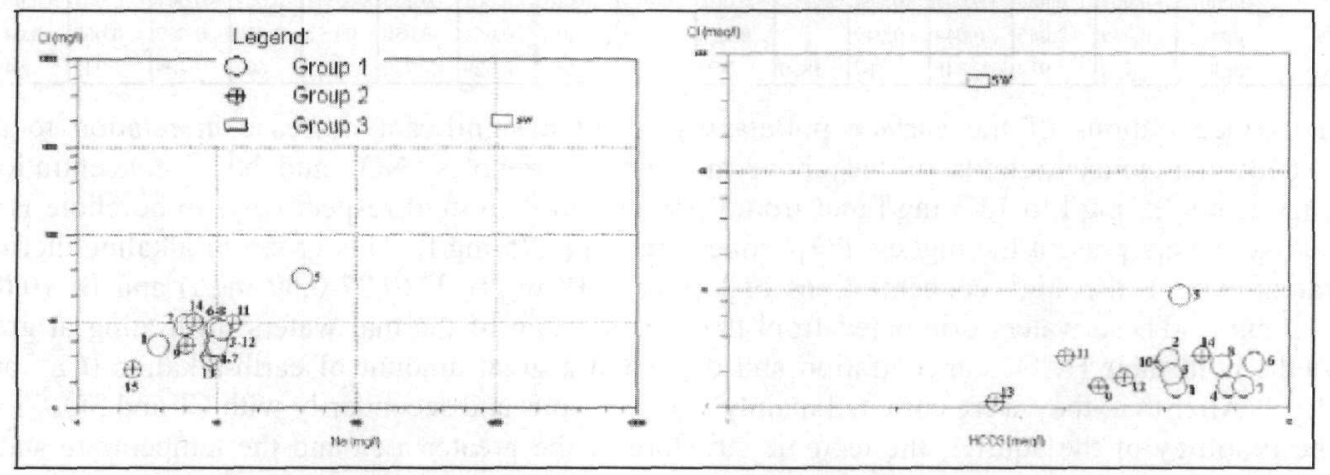

Figure 4 - Ion ratios: $\mathrm{Cl} / \mathrm{Na}$ and $\mathrm{Cl} / \mathrm{HCO}_{3}^{-}$ 
The ion ratio $\mathrm{Na} / \mathrm{Cl}>1$ and especially the ratio $\mathrm{Cl} / \mathrm{Br}$ one, which is the most certain indicator of seawater intrusion (300 seawater indicator) consist a basic parameter supporting the questioning about the seawater intrusion in the hydrothermal reservoir of the area. $\mathrm{Cl} / \mathrm{Br}$ ratio appearing in thermal waters of the area range from 638 to 5316, displaying rather a dilution of evaporates than seawater intrusion.

Table 2 - Ion Ratios of the thermal waters of the study area (meq/l)

\begin{tabular}{|l|l|l|l|l|l|l|l|l|}
\hline $\begin{array}{l}\text { Ion } \\
\text { Ratios }\end{array}$ & $\begin{array}{l}\mathrm{B} 3 \\
\left(25,1^{\circ} \mathrm{C}\right)\end{array}$ & $\begin{array}{l}\mathrm{B} 5 \\
\left(26,2^{\circ} \mathrm{C}\right)\end{array}$ & $\begin{array}{l}\mathrm{B} 7 \\
\left(24,4^{\circ} \mathrm{C}\right)\end{array}$ & $\begin{array}{l}\mathrm{B} 11 \\
\left(28,8^{\circ} \mathrm{C}\right)\end{array}$ & $\begin{array}{l}\mathrm{B} 12 \\
\left(27,9^{\circ} \mathrm{C}\right)\end{array}$ & $\begin{array}{l}\mathrm{B} 13 \\
\left(39,1^{\circ} \mathrm{C}\right)\end{array}$ & $\begin{array}{l}\mathrm{B} 14 \\
\left(24,3{ }^{\circ} \mathrm{C}\right)\end{array}$ & $\begin{array}{l}\mathrm{B} 15 \\
\left(26,2^{\circ} \mathrm{C}\right)\end{array}$ \\
\hline $\mathrm{Na} / \mathrm{Cl}$ & 2,302 & 1,917 & 2,910 & 2,110 & 2,521 & 3,519 & 1,075 & 1,377 \\
\hline $\mathrm{Cl} / \mathrm{Br}$ & 7600 & 12000 & 6000 & 2160 & 1440 & 4400 & 22400 & 229 \\
\hline
\end{tabular}

\subsection{Geothermometry}

The present temperature status of the geothermal reservoir is not clear. Table 3 presents the estimation values of geothermal reservoir temperatures for those boreholes exhibiting higher temperatures according to $\mathrm{SiO}_{2}$ and Chalcedony (Fournier 1977), Na/K (Fournier and Potter 1979), $\mathrm{K} / \mathrm{Mg}$ (Giggenbach 1988) and $\mathrm{Na} / \mathrm{K} / \mathrm{Ca}$ (Fournier 1979) geothermometers.

Table 3 - Temperature estimation $\left({ }^{\circ} \mathrm{C}\right.$ ) of the original geothermal reservoir according to geothermometers

\begin{tabular}{|l|c|c|c|c|c|c|}
\hline Geothermometers & $\begin{array}{c}\mathrm{B} 3 \\
\left(25,1^{\circ} \mathrm{C}\right)\end{array}$ & $\begin{array}{c}\mathrm{B} 5 \\
\left(26,2^{\circ} \mathrm{C}\right)\end{array}$ & $\begin{array}{c}\mathrm{B} 11 \\
\left(28,8^{\circ} \mathrm{C}\right)\end{array}$ & $\begin{array}{c}\mathrm{B} 12 \\
\left(27,9^{\circ} \mathrm{C}\right)\end{array}$ & $\begin{array}{c}\mathrm{B} 13 \\
\left(39,1^{\circ} \mathrm{C}\right)\end{array}$ & $\begin{array}{c}\mathrm{B} 15 \\
\left(26,2^{\circ} \mathrm{C}\right)\end{array}$ \\
\hline $\mathrm{SiO}_{2}$ & 65 & 97 & 73 & 69 & 102 & 83 \\
\hline $\mathrm{Chalcedony}$ & 33 & 67 & 41 & 37 & 73 & 52 \\
\hline $\mathrm{Na} / \mathrm{K}$ & 143 & 82 & 105 & 117 & 89 & - \\
\hline $\mathrm{K} / \mathrm{Mg}$ & 56 & 54 & 53 & 58 & 53 & - \\
\hline $\mathrm{Na} / \mathrm{K} / \mathrm{Ca}$ & 113 & 55 & 49 & 39 & 46 & - \\
\hline
\end{tabular}

According to silica geothermometer, the calculated temperatures range from $65^{\circ} \mathrm{C}$, for the less hot sample, to $102^{\circ} \mathrm{C}$, for the hottest sample. According to Chalcedony geothermometer, the estimated temperatures are much lower from the silica ones, ranging between $33^{\circ} \mathrm{C}$ and $73^{\circ} \mathrm{C} . \mathrm{K} / \mathrm{Mg}$ and $\mathrm{Na} / \mathrm{K} / \mathrm{Ca}$ geothermometers suggest similar temperatures with Chalcedony geothermometer.
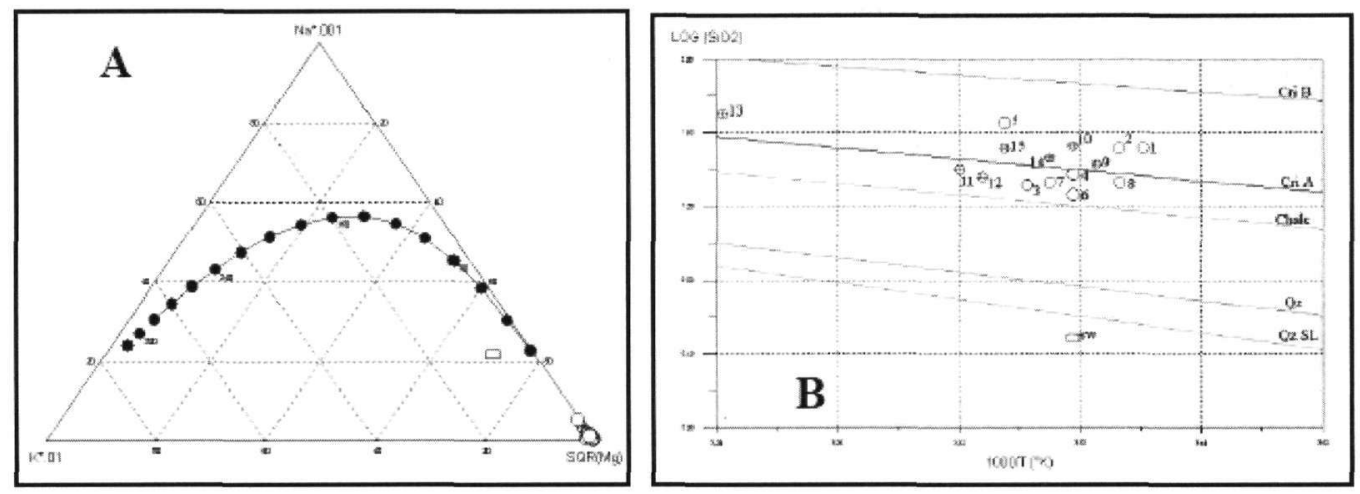

Figure 5 - $\mathrm{Na} / \mathrm{K} / \mathrm{Mg}(\mathrm{A})$ and $\mathrm{SiO}_{2}(\mathrm{~B})$ geothermometer diagrams

According to Giggenbach's (Fig. 5A) triangle diagram, hot samples from surface waters are classified to the "non-equilibrated" group, meaning that groundwaters do not equilibrate with minerals in the reservoir rock. Therefore, the origin temperature could not be clearly estimated. 
However, according to anticipated temperature values from the geothermal reservoir, a rather possible value could be found in the field from $50^{\circ} \mathrm{C}$ to $70^{\circ} \mathrm{C}$, which comprises the estimated, values from $\mathrm{K} / \mathrm{Mg}$ and $\mathrm{SiO}_{2}$ geothermometers. Thus, the study area can be classified to geothermal fields of low enthalpy. These waters have not been circulated in great depths and mixed with marine water as it can be concluded from the chemical composition of the examined hot waters of the area. The acquisition of temperature of these waters could be attributed to the temperature transmission through induction. Therefore, a geothermal system must probably exist, where the heat source is in greater depth and is covered by impermeable formations. Through these formations, heat can be transmitted towards the surface, where the aquifer that hosts the studied waters is located.

\section{Conclusions}

The fractured tectonic in Farsala Basin, combined with the existence of permeable and impermeable formations, create appropriate conditions for the development of an active geothermal system. The geothermal activity observed in the study area is directly connected to the fractured zones of the sub-basement formations. Thermal water temperatures range from $20,5^{\circ} \mathrm{C}$ to $39,1^{\circ} \mathrm{C}$. These waters belong to $\mathrm{Na}-\mathrm{HCO}_{3}, \mathrm{Na}-\mathrm{HCO}_{3}-\mathrm{Cl}$ and $\mathrm{Na}-\mathrm{SO}_{4}-\mathrm{Cl}-\mathrm{HCO}_{3}$ hydrochemical types. The relatively shallow aquifer is characterized by high alkaline concentrations compared to earth-alkaline, suggesting that circulation takes place mainly within volcanic formations, i.e. pillow lavas of the ophiolithic series developed in the broader area of Farsala. The chemical composition of the aquifer is related to processes of hydrolysis of clay-silica minerals, which occur within ophiolithic formations, as well as to dilution of evaporates, which obviously coexist within Neogene formations. The thermal liquids mixture originating from deeper aquifers has not been theoretically validated. The presence of $\mathrm{SO}^{2-}{ }_{4}$ ions is related to oxidation of pyrite, dilution of secondary hydrothermal gypsum, which coexists in limited concentrations within volcanic formations and dilution of Neogene evaporate formations. The limited $\mathrm{Ca}^{2+}$ concentration is obviously related to the precipitation of calcite. The origin of $\mathrm{Cl}^{-}$ions is mainly attributed to the dilution of evaporates and surface influences. According to geothermometric estimations, the possible temperature values of the geothermal reservoir range from 50 to $70^{\circ} \mathrm{C}$ and therefore the study area is classified to low enthalpy geothermal field.

\section{References}

Bornovas, I., Filippakis, N., and Bizon, J.J.G., 1969. Geological Map of Greece 1:50.000, Farsala Sheet. Publication IGME Athens.

Ferriére, J., 1982. Paléogéographies et tectonigues superposées dans les Hellénides internes: les massifs de 1'Othrys et du Pelion (Grèce continentale), Thèse, Univ. des Sciences et Techniques de Lille, S.G.N. $N^{0} 8$, vol. I.

Fournier, R.O., 1977. Chemical geothermometers and mixing models for geothermal systems, Geothermics, 5, 41-50.

Fournier, R.O., 1979. A revised equation for the Na/K geothermometer. Geoth, Resources Council, Trans., 3, 221-224.

Fournier, R.O., and Potter, R.W., 1979. Magnesium correction to the Na-K-Ca chemical geothermometer, Geochim. Cosmochim. Acta, 43, 1543-1550.

Fytikas, M., and Kolios, N., 1979. Preliminary Heat Flow Map of Greece. In V. Germak and L. Rybach (eds), Terastrial Heat Flow in Europe, Springer, 197-205pp.

Gartzos, E., and Stamatis, G., 1996. Genesis of the thermal springs of the Sperchios graben, Greece, N. Jb. Geol. Paläont. Mh., H2. 91-115. 
Giggenbach, W.F., 1988. Geothermal solute equilibria.-Derivation of Na-K-Mg-Ca geoindicators, Geochim. Cosmochim. Acta, 52, 2749-2765.

Kallergis, G., Morphis, A., Papaspyropoulos, Ch., and Christodoulou, Th., 1970. Hydrogeological investigations in the Western Thessaly basin, Hydrological and Hydrogeological Investigations, IGME Athens, No8, 166pp.

Katsikatsos, G., Mylonakis, E., Triantaphyllis, E., Papadeas, G., Psonis, K., Tsaila-Monopoli, S., and Skourtsi-Koroneou, V., 1983. Geological Map of Greece 1:50.000, Velestino Sheet. Publication IGME Athens.

Mariolakos, E., Lekkas, S., Alexopoulos, A., Fountoulis, I., Spyridonos, E., Badekas, I., Mariola-

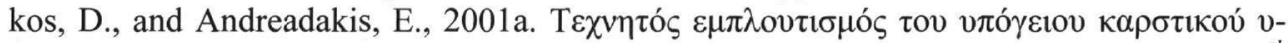

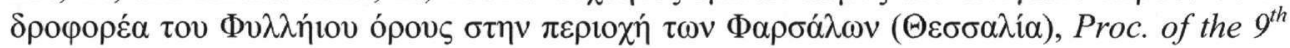
Intern. Congr. Athens, September 2001, Bull. Geol. Greece, vol. XXXIV/5, 1843-1850.

Mariolakos, E., Lekkas, S., Papadopoulos, T., Alexopoulos, A., Fountoulis, I., Alexopoulos, I., Spyridonos, E., Badekas, I., Mariolakos, D., and Andreadakis, E., 2001b. The subsurface tectonic structure of the Farsala basin (Thessaly) as determining factor of the Hydrogeological conditions of the region, Proc. of the $9^{\text {th }}$ Intern. Congr. Athens, September 2001, Bull. Geol. Greece, vol. XXXIV/5, 1851-1858.

Mariolakos, E., Fountoulis, I., Alexopoulos, I., Spyridonos, E., Badekas, I., Mariolakos, D., and Andreadakis, E., 2000. The geometry of the aquifer in the Narthakion Mt. (Thessaly) as a result of the neotectonic deformation, Proc. of the $8^{\text {th }}$ Panhellenic Congr. of EYE, 343350 pp.

Migiros, G., 1990. The lithostratigraphic-tectonic structure of Othris (Central Greece), Bull. Geol. Soc. of Greece, XXVI, 107-120.

Papadeas, G., 1996. Geological and Geothermal exploration in the Sperchios basin (Greece), Energy resources investications, IGME Athens, No3, 80pp.

Sfetsos, K., 1988. Inventory of thermal and mineral springs of Greece, III Continental Greece, $H y$ drological and Hydrogeological Investigations, IGME Athens, No39, 667pp. 